\title{
Knowledge, Attitude, and Practices towards Covid-19 in the Midst of Pandemics among Jakarta Residents
}

\author{
Christine Tan1), Andree Kurniawan²), Devina Adella Halim(1), Felix Wijovi1), Jovita1), \\ Cindy Monika Agatha'), Christin Soputri' ${ }^{1}$, Eva Maria ${ }^{1}$, Sharleen Winata ${ }^{1}$ \\ ${ }^{1)}$ Faculty of Medicine Pelita Harapan University, Indonesia \\ 2)Internal Medicine Department, Faculty of Medicine Pelita Harapan University, Indonesia
}

\section{ABSTRACT}

Background: Jakarta, capital city of Indonesia, had been extremely hit by the COVID-19 pandemic. Public consistence with control measures was important, which was greatly affected by knowledge, attitudes and practices towards COVID-19. This study aimed to investtigate knowledge, attitudes and practices of Jakarta residents for COVID-19.

Subjects and Method: This was an analytic observational study with a cross-sectional design. Sample was gathered online from 221 Jakarta residents, range in age 10 to 60 years, which use self-reported questionnaires consisting of consent, questions about socio-demographics, knowledge, attitudes and practices relevant to COVID-19 and analyzed using t-test and ANOVA. A linear regression analysis was conducted to identify factors associated with knowledge, attitude and practice.

Results: Participants showed moderate level of knowledge $($ mean $=71.20 ; \mathrm{SD}=8.37)$, positive attitudes (mean $=53.47 ; \mathrm{SD}=5.10)$ and moderate practice $($ mean $=78.63 ; \mathrm{SD}=12.73)$. Results demonstrated that women have better knowledge $($ mean $=72.1 ; \mathrm{SD}=9.0 ; \mathrm{p}=0.360)$, optimistic attitudes (mean $=55.1 ; \mathrm{SD}=6.2 ; \mathrm{p}=$ $0.005)$ and great practices $($ mean $=80.1 ; \mathrm{SD}=$ 11.6; $\mathrm{p}=0.316)$ towards COVID-19 than men. Elderly have better knowledge (mean $=75.6$; $\mathrm{SD}=5.0 ; \mathrm{p}=0.001$ ), optimistic attitude (mean= 56.3; $\mathrm{SD}=3.8 ; \mathrm{p}=0.033$ ) and good practices (mean $=82.4 ; \mathrm{SD}=14.3 ; \mathrm{p}=0.301)$ than younger individuals.

Conclusion: Directed approaches in health promotion should be integrated for vulnerable populations, such as men, younger people, and low-income earners who would be at greater risk of COVID-19.

Keywords: COVID-19, Knowledge, Attitude, Practice

\section{Correspondence:}

Andree Kurniawan. Department of Internal Medicine, Faculty of Medicine Pelita Harapan University. Boulevard Jenderal Sudirman, Karawaci, Tangerang, Banten, Indonesia 15811. Email: andree.kurniawan@uph.edu. Mobile: $+62-815-8891-655$.

Cite this as:

Tan C, Kurniawan A, Halim DA, Wijovi F, Jovita, Agatha CM, Soputri C, Maria E, Winata S (2020). Knowledge, Atitude, and Practices towards Covid-19 in the Midst of Pandemics among Jakarta Residents. J Epidemiol Public Health. 05(04): 477-488. https://doi.org/10.26911/jepublichealth.2020.05.04.10.

cc) (i) (-) Journal of Epidemiology and Public Healthis licensed under a Creative Commons Attribution-NonCommercial-ShareAlike 4.0 International License.

\section{BACKGROUND}

Coronavirus disease 2019 (COVID-19) is an emerging acute respiratory disease caused by a novel coronavirus. COVID-19 was first identified in December 2019 in Wuhan, China (Lu et al., 2020) from where it has spread rapidly to more than 200 countries, causing mostly mild upper respiratory tract symptoms and in minority of cases lower respiratory tract infections. It is declared as a global pandemic by World Health Organization (WHO, 2020d).

The virus is highly contagious and easily transmitted from human to human via respiratory droplets and direct contact (WHO, 2020a) which led to the rapidly increasing number of infection and death due to COVID-19 in all over the world. As of 
Tan et al./ Knowledge, Attitude, and Practices towards Covid-19 in the Midst of Pandemics

$16^{\text {th }}$ December 2020 , over 73 million COVID-19 cases were reported with a death count of over 1.6 million patients(WHO, 2020c). The outbreak of coronavirus in Indonesia is officially confirmed to be on $2^{\text {nd }}$ March 2020, when two residents of Depok, West Java tested positive for the virus (WHO, 2020b). Indonesia was reported to be in fourth place among the highest rated countries in Asia, after India, Turkey and Iran, including over 636,000 cases confirmed and over 19,200 deaths (Satuan Satgas Penangan COVID-19, 2020).

Jakarta struggled from a growing number of COVID-19 cases. As of $16^{\text {th }}$ December 2020, the number of confirmed infections was 156,000 and 3,000 death related(Dinas Kesehatan Provinsi DKI Jakarta, 2020). In order to reduce the transmission of the virus and mitigate the possibility of immense healthcare systems, health officials in Indonesia had taken significant efforts, through different approaches, to prevent COVID-19. On March $15^{\text {th }}$ 2020, with 117 confirmed cases, largescale social restrictions were introduced by the Governor of Jakarta, which was the first province to officially do so. Restrictions included the shutdown of public areas, limitation on public transport, and isolation for infected and suspected patients. Only individuals who require "basic needs" and individuals working in certain areas had been permitted to leave their homes and expected to wear face masks.

Many studies have assessed the virological features and clinical significance of COVID-19, but there is not enough studies concentrated on investigating the knowledge and understanding of the infection, basic ideasof infection control and public health crisis assessment that are vital to the development effective control measures, particularly because of a large number of misperceptions and misleading facts shared online. In previous infectious outbreaks including SARS (Deng et al., 2006) and MERS (Nour et al., 2015), this assessment has been shown to be useful as an important way of educating and increasing awareness of standard practice.

The main aim of our current study is to evaluate the degree of knowledge, attitude and practice (KAP) among Jakarta residents toward COVID-19 infection in order to identify related associated demographic characteristics variables during the COVID-19 pandemic.

\section{SUBJECTS AND METHOD}

\section{Study Design}

This was an analytic observational study with a cross-sectional design. This survey was done in April 2020,

\section{Population and Sample}

The population of this study was people aged 10 to 60 years old who resided in Jakarta and given consent to take part and were guided to complete the survey. For this study, a total of 221 participants were analyzed.

\section{Study Variables}

The dependent variable was knowledge, attitudes and practice (KAP towards COVID-19. The independent variables were gender, age, education, occupation, marital status and monthly income.

\section{Operational Definition of Variables}

Gender refers to the socially formed characteristics of women, men, girls and boys.

Age is the length of time that a person has lived.

Education is the process of acquiring instructional support, particularly at a school or university.

Occupation is an activity in which one engages. 
Tan et al./ Knowledge, Attitude, and Practices towards Covid-19 in the Midst of Pandemics

Marital status is the legally defined marital state, which is categorized as single, married, or divorced.

Monthly income is the money earned or obtained, in contrast to the money that must be expended or paid out each month.The monthly income was divided into four categories: < 1.5 million Rupiah, 1.5-2.5 million Rupiah, 2.5-3.5 million Rupiah and $>3.5$ million Rupiah.

Knowledge, practices and attitudes is a survey to gather information on what is understood, believed and conducted in relation to a specific topic.

\section{Study Instruments}

Since we were unable to a communitybased sampling survey, the samples were obtained online. The survey was inserted in the Google Forms and the link was distributed. A broadcast composed of a short overview and a link to the questionnaire was shared with the general public via social networks (e.g. LINE, WhatsApp) in reliance on the author's networks with individuals residing in Jakarta. Before the survey, participants had to confirm one's willingness to participate willingly by addressing a yes-no inquiry and were advised to accomplish the questionnaire self-reportedly.

The questionnaire comprised of four main divisions: 1) Demographic containing demographic information of the participants, including gender, age, education, occupation, marital status and income; 2) COVID-19 knowledge; 3) COVID-19 attitudes; and 4) COVID-19 relevant practices. The contents of the questionnaire used Indonesian language. It was validated by using methods to create the questionnaire from literature review, a preliminary study to identify the questionnaire item and the validity of the material by field expert team testing and approving with external reliability and validity testing.
A total of 50 questions: 20 regarding knowledge, 12 regarding attitudes and 18 regarding practice were included to evaluate the knowledge, attitudes and practices of participants. Knowledge items for COVID19 comprised of (Table 2): 2 in etiology (K1$\mathrm{K} 2), 3$ in transmission routes $\left(\mathrm{K}_{3}-\mathrm{K}_{5}\right), 7$ in risk factor, clinical features and complication (K6-K12), 6 in preventive measures and source of information (K13-K18), 2 in youth participation (K19-K2O). The participants are given the "true" or "false" options for answering. One point was given to a correct answer, while o point was given to an incorrect answer, and the overall score ranged from 0 to 20, which was described as a percentage with better result demonstrating a better COVID-19 knowledge.

Likert scale was used to evaluate attitudes towards COVID-19 (A1-A10, Table 3) as follows: 1 (very not important/ strongly disagree/very not worried), 2 (not important/ disagree/ not worried), 3 (less important/less agreeable/less worried), 4 (important/ agree/ worried), 5 (very important/ very much agree/very worried). By summing the raw scores of the 12 questions, which ranged from 12 to 50 , the overall score was calculated, with a higher total score showing a more positive attitude towards COVID-19.

To measure practice action (P1-P10, Table 4), participants responded to each item as "yes" or "no". The overall score ranged from o to 18 and was shown as a percentage, with a higher score demonstrating more regular COVID-19 practice.

\section{Data Analysis}

All of the data gatheredwasinputted into SPSS version 25.0 software. Descriptive analysis focuses on frequency and percentage. Independent sample t-test and oneway variance analysis (ANOVA) were used to differentiate KAP from different participants in respect to demographic variables. 
Tan et al./ Knowledge, Attitude, and Practices towards Covid-19 in the Midst of Pandemics

The level of statistical significance was fixed at $\mathrm{p}<0.05$. In order to recognize factors associated with KAP, a linear regression analysis was conducted.

\section{Research Ethic}

The Ethic Committee of Faculty of Medicine, Pelita Harapan University approved our study protocol on April 21 2020 with No. 137/K-LKJ/ETIK/IV/2020. An online link was provided to participants who agreed to participate willingly by signing a consent form containing details of the research objective.

\section{RESULTS}

\section{Characteristics of Sample}

Demographic characteristics of participants based on gender, age group, education, occupation, marital status and income category were shown in Table 1. A total of 226 residents participated in this research. The final sample consisted of 221 participants, with exclusion of 5 participants over 60 years of age. The mean age was 25.25 years $($ mean $=25.25 ; \mathrm{SD}=10.12)$ going from 12 to 60 years. Most participants were men (73.76\%), students (48.42\%), those who held a middle school and high school degree (58.82\%) unmarried (82.81\%), and those whose monthly income was $<1.5$ million Rupiah (45.70\%).

Table 1. Demographic characteristics of participants

\begin{tabular}{llcc}
\hline \multicolumn{1}{c}{ Characteristics } & \multicolumn{1}{c}{ Category } & Frequency & Percentage \\
\hline Gender & Male & 163 & 73.76 \\
Age & Female & 58 & 26.24 \\
& $10-18$ & 59 & 26.70 \\
& $19-25$ & 88 & 39.82 \\
Education & $26-40$ & 50 & 22.62 \\
& $41-60$ & 24 & 10.86 \\
Occupation & Primary & 7 & 3.17 \\
& Secondary & 130 & 58.82 \\
& Tertiary & 84 & 38.01 \\
& Students & 107 & 48.42 \\
& Private sector & 59 & 26.70 \\
& Public sector & 6 & 2.71 \\
& Self-employed & 26 & 11.76 \\
Marital Status & Others & 12 & 5.43 \\
& Unemployed & 11 & 4.98 \\
& Single & 183 & 82.81 \\
Monthly Income & Married & 36 & 16.29 \\
& Divorced & 2 & 0.905 \\
& $<1.5$ million Rupiah & 101 & 45.70 \\
& $1.5-2.5$ million Rupiah & 17 & 7.69 \\
& $2.5-3.5$ million Rupiah & 19 & 8.60 \\
& $>3.5$ million Rupiah & 84 & 38.01 \\
\hline
\end{tabular}

\section{Bivariate Analysis}

Table 2 show result of bivariate analysis comparison of sociodemographic character- ristics and mean knowledge, atitude, and practices score: 
Tan et al./ Knowledge, Attitude, and Practices towards Covid-19 in the Midst of Pandemics

Table 2. Comparison of sociodemographic characteristics and mean knowledge, attitudes, and practices score

\begin{tabular}{|c|c|c|c|c|c|c|c|c|c|}
\hline \multirow{2}{*}{$\begin{array}{c}\text { Independent } \\
\text { Variable }\end{array}$} & \multicolumn{3}{|c|}{ Knowledge score } & \multicolumn{4}{|c|}{ Attitude score } & \multicolumn{2}{|c|}{ Practice score } \\
\hline & Mean & SD & $\mathbf{p}$ & Mean & SD & $\mathbf{p}$ & Mean & SD & $\mathbf{p}$ \\
\hline \multicolumn{10}{|l|}{ Gender } \\
\hline Male & 70.89 & 8.13 & \multirow[t]{3}{*}{0.360} & 52.90 & 4.56 & \multirow[t]{3}{*}{0.005} & 78.12 & 13.09 & \multirow[t]{3}{*}{0.316} \\
\hline Female & 72.07 & 9.03 & & 55.07 & 6.16 & & 80.08 & 11.63 & \\
\hline Age Group & & & & & & & & & \\
\hline $10-18$ & 68.14 & $7 \cdot 36$ & \multirow{4}{*}{0.001} & 52.76 & 4.37 & \multirow{4}{*}{0.033} & 79.10 & 12.26 & \multirow{4}{*}{0.301} \\
\hline $19-25$ & 71.25 & 7.78 & & 53.30 & 4.56 & & 77.02 & 12.78 & \\
\hline $26-40$ & 72.60 & 10.41 & & 53.24 & 6.78 & & 79.11 & 12.32 & \\
\hline $\begin{array}{l}\text { 41-60 } \\
\text { Education Levels }\end{array}$ & 75.63 & 4.96 & & 56.29 & 3.79 & & 82.41 & 14.25 & \\
\hline $\begin{array}{l}\text { Primary } \\
\text { education }\end{array}$ & 69.29 & 13.05 & \multirow[t]{3}{*}{$<0.001$} & 52.57 & 4.93 & \multirow[t]{3}{*}{0.428} & 76.19 & 10.98 & \multirow[t]{3}{*}{0.797} \\
\hline $\begin{array}{l}\text { Secondary } \\
\text { education }\end{array}$ & 69.35 & 7.98 & & 53.15 & 4.49 & & 79.02 & 12.57 & \\
\hline $\begin{array}{l}\text { Tertiary } \\
\text { education }\end{array}$ & 74.23 & 7.70 & & 54.02 & 5.96 & & 78.24 & 13.20 & \\
\hline \multicolumn{10}{|l|}{ Occupation } \\
\hline Student & 70.00 & 7.24 & \multirow[t]{6}{*}{0.040} & 52.94 & 4.53 & \multirow[t]{6}{*}{0.036} & 78.87 & 12.76 & \multirow[t]{6}{*}{0.803} \\
\hline Private Sector & 73.14 & 7.98 & & 54.66 & 3.97 & & 77.87 & 12.23 & \\
\hline Public Sector & 77.50 & 8.80 & & 48.00 & 16.37 & & 74.07 & 7.59 & \\
\hline Self-employed & 70.38 & 12.16 & & 53.65 & 4.77 & & 80.34 & 13.81 & \\
\hline Other & 73.75 & 5.69 & & 54.50 & 4.62 & & 76.38 & 17.10 & \\
\hline $\begin{array}{l}\text { Unemployed } \\
\text { Marital Status }\end{array}$ & 68.18 & 9.56 & & 53.55 & 4.41 & & 81.31 & 10.32 & \\
\hline Single & 70.74 & 8.18 & \multirow[t]{4}{*}{0.103} & 53.30 & 4.49 & \multirow[t]{3}{*}{0.376} & 77.81 & 12.50 & \multirow[t]{3}{*}{0.099} \\
\hline Married & 73.06 & 9.05 & & 54.08 & 7.57 & & 82.41 & 13.57 & \\
\hline Divorced & 80.00 & 7.07 & & 57.50 & 0.71 & & 86.11 & 3.93 & \\
\hline Income & & & & & & & & & \\
\hline $\begin{array}{l}<1.5 \text { million } \\
\text { Rupiah }\end{array}$ & 69.51 & 7.67 & \multirow[t]{4}{*}{0.035} & 52.64 & 4.54 & \multirow[t]{4}{*}{0.148} & 79.86 & 12.29 & \multirow[t]{4}{*}{0.596} \\
\hline $\begin{array}{l}1.5^{-2.5} \text { million } \\
\text { Rupiah }\end{array}$ & 72.35 & 6.64 & & 54.53 & 3.92 & & 78.10 & 10.48 & \\
\hline $\begin{array}{l}2.5-3.5 \text { million } \\
\text { Rupiah }\end{array}$ & 71.05 & 10.08 & & 53.42 & 4.73 & & 76.61 & $13 \cdot 30$ & \\
\hline $\begin{array}{l}>3.5 \text { million } \\
\text { Rupiah }\end{array}$ & 73.04 & 8.78 & & 54.25 & 5.89 & & 77.71 & 13.57 & \\
\hline
\end{tabular}

Tabel 2 showed that the knowledge score of participants aged 41-60 years was $75.64($ Mean $=75.64 ; \mathrm{SD}=4.96 ; \mathrm{p}=0.001)$, education was 74.23 (mean $=74.23 ; \mathrm{SD}=$ 7.70; p<0.001), occupation was 77.50 $(\mathrm{Mean}=77.50 ; \mathrm{SD}=8.80 ; \mathrm{p}=0.040)$, marital status was 80 (Mean $=80 ; \mathrm{SD}=7.07 \mathrm{p}=$ 0.103 ), and income was 73.04 (mean= 73.04; $\mathrm{SD}=8.78 \mathrm{p}=0.035$ ).

Attitude scrore of participants aged 41-6o years was $($ Mean $=55.07 ; \mathrm{SD}=6.16$; $\mathrm{p}=0.005)$, education was $(\mathrm{Mean}=56.29$; $\mathrm{SD}=3.79 ; \mathrm{p}=0.033)$, occupation was 54.66 $(\mathrm{Mean}=54.66 ; \mathrm{SD}=3.97 ; \mathrm{p}=0.036)$, mari- tal status was $57.50 \quad($ Mean $=57.50 ; \mathrm{SD}=$ $0.71 ; \mathrm{p}=0.376)$, and income category was 54.53 (Mean= 54.53; $\mathrm{SD}=5.89 ; \mathrm{p}=0.148)$.

Practice score of participants aged 4160 years was 80.08 (Mean $=80.08$; $\mathrm{SD}=$ 11.63; $\mathrm{p}=0.0361$ ), education was 82.41 (Mean= 82.41; $\mathrm{SD}=14.25 ; \mathrm{p}=0.301)$, occupation was 81.31 (Mean= 81.31; $\mathrm{SD}=10.32$; $\mathrm{p}=0.803$ ), marital status was 86.11 (Mean= 86.11; $\mathrm{SD}=3.93 ; \mathrm{p}=0.099)$, and income was $79.86($ Mean $=79.86 ; \mathrm{SD}=12.29 ; \mathrm{p}=$ 0.596). 
Tan et al./ Knowledge, Attitude, and Practices towards Covid-19 in the Midst of Pandemics

\section{DISCUSSION}

COVID-19 was a new virus with high probability of transmission, causing the pandemic. The published KAP data for COVID-19 were still limited in Indonesia so far. With its uncertainties, the potential threat that COVID-19 posed implied that health officials need to develop effective and precautionary interventions to mitigate rates of infection and regulate the transmission of virus. It was therefore vitally essential that the KAP of the general populace to be evaluated to direct these measures.

Jakarta residents had a moderate average knowledge score (mean $=71.20$; $\mathrm{SD}=8.34$ ), indicating that most participants were educated concerning COVID-19. The results were consistent with a study conducted in China among urban and rural residents with a total correct knowledge percentage of $61.9 \%$, implying that the level of understanding was moderate (Yue et al., 2020). In our study, it was not surprising that the level of knowledge was medium level, because majority of the participants (58.82\%) held middle school or high school degrees. There was a broad range of understanding, stating that some participants had a substantial degree of awareness about COVID-19, while others did not.

Most participants (98.19\%) were aware of the clinical manifestations. Between individuals who were close together, viral infections were noted as incredibly contagious (Sanche et al., 2020). This was congruent with our findings that majority of the participants were conscious that the virus could be transmitted, $96.38 \%$ and 99.10\% respectively, through direct contact with respiratory droplets from an infected person and touching surfaces contaminated with the virus.

Age, education, and income had been studied to be strongly associated to knowledge (Beier and Ackerman, 2003). Age ( $p=$
0.001), education $(\mathrm{p}<0.001)$, occupation (0.040) and income (0.035) were the significant variables of the participants' knowledge. Participants in the 41-60 age group had a higher level of awareness (mean= 75.63; $\mathrm{SD}=4.96$ ), possibly due to a perceived increased likelihood of being contracted and disease complications (Cao et al., 2020).

There was a higher level of knowledge for participants holding a tertiary education degree $($ Mean=74.23; $\mathrm{SD}=7.70)$. Due to the severe pandemic situation and the incredible amount of public health emergency reports, this group would obtain more information regarding the disease from various media. Higher education degree participants might be linked to greater learning capacity and intelligence, enabling them to easily acknowledge information of COVID-19.

Participants holding a primary education level with a lower knowledge score (Mean= 69.29; $\mathrm{SD}=13.05$ ) might be influenced by their minimal exposure since the pandemic to government information relevant to COVID-19. This assumption was reinforced by the significant positive association between the degree of education and the COVID-19 knowledge score. This result was comparable to a study carried out in Egypt (Abdelhafiz et al., 2020).

Other studies had supported these findings also, demonstrating that older and more educated participants were more knowledgeable about contagious diseases (Al-Mohrej et al., 2016). Other studies carried out on Indonesian adolescents indicated that youths had more-or-less knowledge about COVID-19, in which the practice of physical distancing and hand washing seemed poorly understood (Halim et al., 2020). Moreover, the lack of urgency in COVID-19 confirmed cases and deaths attributed to the reluctancy of Jakarta resi- 
Tan et al./ Knowledge, Attitude, and Practices towards Covid-19 in the Midst of Pandemics

dents to obtain knowledge about COVID19. Therefore, the public with lower academic backgrounds should be addressed properly to health education. The focus of health promotion should be on individuals of different educational backgrounds and different interests. For the population with low levels of education, simple material could be more feasible.

Highearners $\quad($ mean $=73.04 ; \quad \mathrm{SD}=$ 8.78) were more informed regarding Covid19. Due to poor accessibility to precise and timely information about COVID-19, lower earners had lower level of knowledge (mean=69.51; SD= 7.67). Although Covid19 information had been propagated continuously by health officials since the first case identified in Jakarta, there had also been a spike in misleading information and factual inaccuracies (Nasir et al., 2020). Information overload could lead to misunderstandings and trouble assuring accurate information. In order to increase one's perceptions of COVID-19 through awareness-rising strategies, special emphasis should be mounted on youths, less educated and low earners. Several other studies conducted in another Asian countries had shown a great degree of awareness of COVID-19 across the public (Zhong et al., 2020) and healthcare professionals (Huynh et al., 2020).

Female seemed to have greater understandings $($ mean $=72.07 ; \mathrm{SD}=9.03)$ than male participants $($ mean $=70.89 ; \mathrm{SD}=$ 8.13), which was consistent with the findings discovered in the study in China (Zhong et al., 2020) and Malaysia (Azlan et al., 2020). This could be due to greater involvement of male participants that had poor educational backgrounds in our study. Females were also much more actively involved in information regarding health using the Internet (Bidmon and Terlutter,
2015) and $62.1 \%$ of the women in this study held a tertiary education degree.

Single participants $($ mean $=70.74$; $\mathrm{SD}=8.18$ ) had a lower understanding than married (mean=73.06; $\mathrm{SD}=9.05)$ and divorced participants (mean $=80.00 ; \mathrm{SD}=$ 7.07), which was consistent with the study conducted in the United States (Wolf et al., 2020). This might be attributed to a middle school of high school degree held by $73.77 \%$ of the single participants and $80.33 \%$ of the single participants were 10-25 years old, which had lower understanding.

There were multiple efforts done by the government. A thorough public awareness program was conducted by the Indonesian Ministry of Health via websites, television and diverse social media. The Ministry of Health had established COVID-19 protocols to provide facts and data on prevention. Intentions to cause citizens to be actively engaged in control and preventive strategies to address misinformation and misunderstandings that had evolved rapidly (Cabinet Secretariat of the Republic of Indonesia, 2020).

To avoid transmission of virus, one's understanding regarding COVID-19 was intended to affect their beliefs and actions towards COVID-19. A study showed that increasing awareness of transmission of pandemic diseases and various approaches could strengthen the efficacy of pandemic prevention programs (Saunders-Hastings and Krewski, 2016).

Most participants were positive about COVID-19 $($ mean $=53.57 ; \quad \mathrm{SD}=5.10)$. Similarly, a KAP study led in Saudi Arabia showed positive attitude, which was attributed by the authors to the drastic actions directed by the government of Saudi Arabia to decrease cases. The optimistic attitude towards managing COVID-19 could be asserted by the extreme and immediate reaction of health authorities to take strict 
Tan et al./ Knowledge, Attitude, and Practices towards Covid-19 in the Midst of Pandemics

control and preventive measures to protect residents and preserve their well-being. In Jakarta, the efforts were large-scale social restrictions, closure of schools and universities, banning of religious activities and gatherings, workplace and tourism sector. Such results were similar to a research carried out in Saudi Arabia, in which most participants felt it was essential to maintain a minimum distance and to practice hand washing to protect against COVID-19 (AlHanawi et al., 2020). Nevertheless, these findings were in conversely to other survey, which showed that people would generally show negative thoughts, such as panic and anxiety, during a disease outbreak which might affect their behavior (Blendon et al., 2004).

Nearly $93 \%$ of the participants were anxious about their relatives of contracting the disease, which might be due to the incompetent management, such as a shortage of adequate and comprehensive testing facilities and lack of personal protective equipment (PPE). Previously, the home quarantine scheme was ignored by Jakarta residents, which advanced the total of positive patients. The dense population causes it to be impractical to keep social distances in marketplace that remained open during the period of large-scale social restrictions. Majority of the participants (95.93\%) demonstrated that it was incredibly important to maintain a minimum distance of 2 meters to prevent transmission. This could have been attributable to the precautionary actions that the government and the media had put more emphasis on. Furthermore, the understanding of the probability of transmission through sneezing (respiratory droplets) emphasized the significance of social distancing (Zhong et al., 2020).

Although the attitude was optimistic, majority of the participants were anticipated to prevent being contracted. Almost
99\% of participants practiced cough ethics to eliminate direct contact with respiratory droplets, 96.83\% used face masks, 93.67\% practiced proper hand washing techniques, 89.14\% studied and worked from home, and $82.81 \%$ avoided crowded areas. This had shown participants' comprehensive readiness of participants during the Covid19 pandemic to make behavioral adjustments. This was similar to other survey that demonstrated moderate practice in prevention of dengue hemorrhagic fever in Jakarta (Martina et al., 2018). High percentages of good practices were shown by lower income earners $($ mean $=79.86 ; \mathrm{SD}=12.29)$ because higher income earners (mean=77.71; $\mathrm{SD}=$ 13.57) were not so much concerned(Raude and Setbon, 2009) and less willing to cooperate to health guidelines (Wong et al., 2016).

Residents obeying these preventive actions might be due to the local official's rapid control measures, in particular the prohibition of social gatherings and the closure of all academic institutions. Nevertheless, this research showed that $17.19 \%$ of participants went to crowded areas and $3.17 \%$ did not wear masks, which was significantly greater than a surveycarried out in China (Zhonget al., 2020), which might be due to Indonesia's worse socioeconomic conditions than China. This might force particular individuals to leave their homes to work as they had no other choice. Males, primary education degrees and youths were linked to these potentially risky practices. Previous studies in terms of age and gender, men and late adolescents were more likely to be involved in risk-taking habits (Pawlowski et al., 2008; Cobey et al., 2013; Duell et al., 2018). For all demographic variables, the outcome of the practice scores was not significant. This might be associated to the fact that positive cases in Jakarta continue to increase until today. 
Tan et al./ Knowledge, Attitude, and Practices towards Covid-19 in the Midst of Pandemics

COVID-19 had been emerging health issue in the world of public health. Researchers had been trying to discover different treatment options and immunizations. In order to plan health education programs, researchers in the public health and health communication sector attempted to investigate KAP towards COVID-19 across the public. The current study indicated the need for a more extensive health education program, highlighting the consistency health officials' information. Community health education could raise the awareness about infectious diseases and adhere with individuals' healthy lifestyle(Kumar and Preetha, 2012). Attempts to empower individuals regarding COVID-19 should be conducted out with comprehensive interventions and emphasize the elimination of misunderstanding and misleading information. The results of this study might be helpful for health professionals and officials about supplemental plans and practices for health promotion, approaches in public health and increasing awareness.

The results of this research might be effective in assisting healthcare professionals and health officials further about policies and programs for health education, interventions in public health and increasing awareness.

In analyzing the results of this study, several limitations had to be considered. Participants were mainly men and students, which might limit the generalizability of our findings. The data collected in this study was self-reported, which might be prone and susceptible to reporting bias. In order to solve these issues, future studies may use administrative data and investigate KAP in a more diverse sample of population. There might also be some endogenous variables, such as perceptions and aspirations towards government and personal hygiene, where we did not have a genuine tool to exclude the endogeneity. Furthermore, it was unfeasible to conduct national community-based sampling surveys over a certain period. Hence, data was collected selfreportedly via online, relying on the network of the authors.

Our results showed that there were moderate knowledge, positive attitudes and moderate practice towards COVID-19 among Jakarta residents. Women had better COVID-19 understanding, positive attitude and excellent practices than men. Acknowledging the source and cause of COVID-19 transmission had enhanced the public's ability to become more aware of contagious disease transmission and to take precautions to prevent transmission. Additional emphasis should be placed on men, less educated and low-income earners.

\section{AUTHOR CONTRIBUTION}

All the authors conceptualized the study, outlined the designed, and supervised data analysis. Christine Tan and Andree Kurniawan wrote the manuscript and worked out the relevant details. All authors have read and approved the final manuscript.

\section{CONFLICT OF INTEREST}

There is no conflict of interest in this study.

\section{FUNDING AND SPONSORSHIP}

None.

\section{ACKNOWLEDGEMENT}

The authors would like to thank all the participants involved in this study.

\section{REFERENCE}

Abdelhafiz AS, Mohammed Z, Ibrahim ME, Ziady HH, Alorabi M, Ayyad M, Sultan EA (2020). Knowledge, perceptions, and attitude of egyptians towards the novel Coronavirus disease (COVID-19). J Community Health. 45: 881-890. https://dx.doi.org/10.- 
Tan et al./ Knowledge, Attitude, and Practices towards Covid-19 in the Midst of Pandemics

1007\%2Fs10900-020-00827-7.

Al-Hanawi MK, Angawi K, Alshareef N, Qattan AMN, Helmy HZ, Abudawood $\mathrm{Y}$, Alqurashi M, et al. (2020). Knowledge, attitude and practice toward COVID-19 among the public in the Kingdom of Saudi Arabia: A crosssectional study. Frontiers in Public Health. 8: 217. https://dx.doi.org/10$.3389 \% 2 F f p u b h .2020 .00217$.

Al-Mohrej OA, Al-Shirian SD, Al-Otaibi SK, Tamim HM, Masuadi EM, Fakhoury HM (2016). Is the Saudi public aware of Middle East respiratory syndrome?. J Infect Public Health. 9(3): 259-266. https://dx.doi.org/10.1016\%2Fj.jiph.2 015.10.003.

Azlan AA, Hamzah MR, Sern TJ, Ayub SH, Mohamad E (2020). Public knowledge, attitudes and practices towards COVID-19: A cross-sectional study in Malaysia. PLoS ONE. 15(5): eo233668. https://dx.doi.org/10.1371\%2Fjournal.pone.0233668.

Badan Pusat Statistik (2018). Statistik Pemuda Indonesia 2018. Jakarta: Badan Pusat Statistik, Jakarta - Indonesia.

Beier ME, Ackerman PL (2003). Determinants of health knowledge: An investigation of age, gender, abilities, personality, and interests. J Pers Soc Psychol. 84(2): 439-48. https://content.apa.org/doi/10.1037/o022-3514.84.2.439.

Bidmon S, Terlutter R (2015). Gender differences in searching for health information on the internet and the virtual patient-physician relationship in Germany: Exploratory results on how men and women differ and why. J Med Internet Res. 17(6): e156. https://doi.org/10.2196/jmir.4127.

Blendon RJ, Benson JM, DesRoches CM, Raleigh E, Taylor-Clark K (2004). The public's response to severe acute respiratory syndrome in Toronto and the United States. Clin Infect Dis. 38(7): 925-931. https://doi.org/10.10$86 / 382355$.

Cabinet Secretariat of the Republic of Indonesia (2020) Gov't Unveils Three Strategies to Combat COVID-19. Available at: https://setkab.go.id/en/govt-unveils-three-strategies-tocombat-covid-19/ (Accessed: December, 2020).

Cao J, Hu X, Cheng W, Yu L, Tu WJ, Liu Q (2020). Clinical features and shortterm outcomes of 18 patients with corona virus disease 2019 in intensive care unit. Intensive Care Med. 46: 851-853. https://doi.org/10.1007/so0134-020-05987-7.

Cobey KD, Stulp G, Laan F, Buunk AP, Pollet TV (2013). Sex differences in risk taking behavior among dutch cyclists. Evol Psychol. 11(2): 350-364. doi: 10.1177/147470491301100206.

Deng JF, Olowokure B, Kaydos-Daniels SC, Chang HJ, Barwick RS, Lee ML, Deng CY, et al. (2006). Severe acute respiratory syndrome (SARS): Knowledge, attitudes, practices and sources of information among physicians answering a SARS fever hotline service. Public Health. 120(1): 15-19. https://dx.doi.org/10.1016\%2Fj.puhe.2005.1 o.001.

Dinas Kesehatan Provinsi DKI Jakarta (2020) Data Pemantauan COVID-19 DKI Jakarta.

Duell N, Steinberg L, Icenogle G, Chein J, Chaudhary N, Giunta LD, Dodge KA, et al. (2018). Age patterns in risk taking across the world. J Youth Adolesc. 47(5): 1052-1072. https://doi.org/10.1007/s10964-017-0752-y.

Halim DA, Kurniawan A, Agung FH, Angelina S, Jodhinata C, Winata S, Frenstan, et al. (2020). Understanding of 
Tan et al./ Knowledge, Attitude, and Practices towards Covid-19 in the Midst of Pandemics

young people about COVID-19 during early outbreak in Indonesia. Asia-Pac J Public Health. 32(6-7): 363-365. https://doi.org/10.1177\%2F10105395 20940933.

Huynh G, Nguyen TNH, Tran VK, Vo KN, Vo VT, Pham LA (2020). Knowledge and attitude toward COVID-19 among healthcare workers at District 2 Hospital, Ho Chi Minh City. Asian Pac J Trop Med. 13(6): 260-265. doi: 10.4103/1995-7645.280396.

Kumar S, Preetha GS (2012). Health promotion: An effective tool for global health. Indian $\mathrm{J}$ Community Med. 37(1): 5-12. https://dx.doi.org/10.4103\%2F0970-0218.94009.

Lu R, Zhao X, Li J, Niu P, Yang B, Wu H, Wang W, et al. (2020). Genomic characterisation and epidemiology of 2019 novel coronavirus: implications for virus origins and receptor binding. The Lancet. 395(10224): 565-574. https://doi.org/10.1016/So1406736(20)30251-8.

Martina SE, Bratajaya CNA, Ernawati E (2018). Dengue hemorrhagic fever: Knowledge, attitude, and practice in Palmeriam, Jakarta, Indonesia. Global Health Manage J. 2(1): 9. doi: 10.35898/ghmj-21184.

Nasir NM, Baequni B, Nurmansyah MI (2020). Misinformation related to COVID-19 in Indonesia. Jurnal Administrasi Kesehatan Indonesia. 8(2): 51-59. http://dx.doi.org/10.20473/jaki.v8io.2020.51-59.

Nour MO, Babilghith AO, Natto HA, AlAmin FO, Alawneh SM (2015). Knowledge, attitude and practices of healthcare providers towards MERS-CoV infection at Makkah hospitals, KSA. Int Res J Med Med Sci. 3(4): 103-112. http://www.netjournals.org/pdf/IRJ MMS/2015/4/15-046.pdf.
Pawlowski B, Atwal R, Dunbar RIM (2008). Sex differences in everyday risktaking behavior in humans. Evolutionary Psychology. 6(1): 29-42. https://psycnet.apa.org/doi/10.1177/14747 0490800600104.

Raude J, Setbon M (2009). Lay perceptions of the pandemic influenza threat. Eur J Epidemiol. 24(7): 339-342. https://doi.org/10.1007/s10654-009-9351-x.

Sanche S, Lin YT, Xu C, Romero-Severson E, Hengartner N, Ke R (2020). High contagiousness and rapid spread of severe acute respiratory syndrome Coronavirus 2. Emerging Infectious Diseases. 26(7): 1470-1477. https://dx.doi.org/10.3201/eid2607.200282.

Satuan Satgas Penangan COVID-19 (2020) Peta Sebaran, Komite Penanganan COVID-19 dan Pemulihan Ekonomi Nasional. Available at: https://covid19.go.id/peta-sebaran (Accessed: December 12, 2020).

Saunders-Hastings PR, Krewski D (2016). Reviewing the history of pandemic influenza: Understanding patterns of emergence and transmission. Pathogens. 5(4): 1-19. doi: 10.3390/pathogens5040066.

WHO (2020a). Coronavirus disease (COVID-19): How is it transmitted?.

WHO (2020b). Coronavirus Disease 2019 (COVID-19) World Health Situation Report - 1. WHO Indonesia Situation Report, 2019(March).

WHO (2020c). WHO Coronavirus Disease (COVID-19) Dashboard.

WHO (2020d) WHO Director-General's opening remarks at the mission briefing on COVID-19.

Wolf MS, Serper M, Opsasnick L, O'Conor RM, Curtis LM, Benavente JY, Wismer G, et al. (2020). Awareness, attitudes, and actions related to COVID19 among adults with chronic condi- 
Tan et al./ Knowledge, Attitude, and Practices towards Covid-19 in the Midst of Pandemics

tions at the onset of the U.S. Outbreak: A cross-sectional survey. Annals of internal medicine. 173(2): 100-109. https://dx.doi.org/10.7326\%2FM2O-1239.

Wong KK, Cohen AL, Norris SA, Martinson NA, von Mollendorf C, Tempia S, Walaza S, et al. (2016). Knowledge, attitudes, and practices about influenza illness and vaccination: a crosssectional survey in two South African communities. Influenza and other Respiratory Viruses. 10(5): 421-428. https://dx.doi.org/10.1111\%2Firv.123 88.

Yue S, Zhang J, Cao M, Chen B (2020).
Knowledge, attitudes and practices of COVID-19 among urban and rural residents in China: A cross-sectional study. Journal of Community Health. 1-6. https://dx.doi.org/10.1007\%2Fs10900-020-00877-x.

Zhong BL, Luo W, Li HM, Zhang QQ, Liu XG, Li WT, Li Y (2020). Knowledge, attitudes, and practices towards COVID-19 among chinese residents during the rapid rise period of the COVID-19 outbreak: A quick online cross-sectional survey. Int J Biol Sci. 16(10): 1745-1752. https://dx.doi.org/10.7150\%2Fijbs.45221. 